\title{
Original Research \\ Road Traffic Noise Exposure in the City of Novi Sad: Trend Analysis and Possible Solutions
}

\author{
Bojan Djercan*, Milka Bubalo-Zivkovic, Tamara Lukic, \\ Milana Pantelic, Slobodan Markovic \\ Department of Geography, Tourism and Hotel Management, Faculty of Sciences, University of Novi Sad, \\ Trg Dositeja Obradovida 3, 21000 Novi Sad, Serbia
}

Received: 6 August 2014

Accepted: 13 October 2014

\begin{abstract}
This paper evaluated exposure to road traffic noise in the city of Novi Sad, the second largest city in the Republic of Serbia. It has been investigated using analysis and systematization of the results on noise intensity in the city of Novi Sad, whether this parameter is within the approved limits for noise intensity during the day and night and whether it is in accordance with provisions of national norms of permissible noise levels in the environment, that is whether this parameter endangers people or not. In this work were used data from the Institute for Public Health of Vojvodina-Department of Residential Hygiene, which were obtained by measuring the noise intensity at 18 points in the city. Levels of noise, during the period of analysis, are usually higher than permitted and range from $1 \mathrm{~dB}(\mathrm{~A})$ to $8 \mathrm{~dB}(\mathrm{~A})$ during the day, and from $1 \mathrm{db}(\mathrm{A})$ to $9 \mathrm{~dB}(\mathrm{~A})$ at night. It has been determined that the noise intensity is in strong positive correlation $\left(r_{s}=0.73\right)$ with the number of vehicles in traffic. Even though the noise intensity in the period observed has a decreasing trend, the fact that it is still higher than permitted in school and residential zones is particularly worrying. It has also been determined that traffic noise is one of the leading urban problems in the city of Novi Sad, and therefore it is necessary to implement some of the plans for protection, mentioned in the work, for its reduction.
\end{abstract}

Keywords: road noise pollution, traffic, environment, City of Novi Sad, Serbia

\section{Introduction}

Noise is a naturally unpleasant experience, which is present all the time as a harmful factor in the environment and is among the physical factors harmful to health. The European Union has marked road traffic noise in the environment as one of the leading ecological problems in Europe [1]. According to data of the World Health Organization (WHO), the basic level of road traffic noise increases for one $\mathrm{dB}(\mathrm{A})$ every year. About 120 million people have hearing problems. In the European Union, approximately $40 \%$ of the population is exposed to residential noise levels of above $55 \mathrm{~dB}(\mathrm{~A})$ during daytime and more

*e-mail: bojandjercan@yahoo.co.uk than $30 \%$ are exposed to the same noise levels at night. This exposure may cause serious annoyance and sleep disturbance. Therefore, noise represents one of the leading risk factor distortions of overall health integrity [2, 3].

The EU gives a lot more consideration to this problem than other parts of the world [4]. According to the references of the European Commission, all members of the European Union are obligated to produce strategic noise maps for urban areas with populations of over 250,000 [5].

Noise is a specific form of pollution in the modern world. It was observed as a problem at the beginning of urbanization and housing in the cities, and it became a serious ecological problem with the beginning of industrialization at the end of the $18^{\text {th }}$ and the beginning of the $19^{\text {th }}$ centuries. The development of modern technologies, urbaniza- 
tion, and rapid industrialization, especially the development of traffic and the car industry, have led to noise as a serious ecological problem of the modern world [6-13].

Nowadays, exposure to noise is one of the most important criteria in the selection of a residence $[14,15]$. Research indicates the high influence of road traffic noise on front building facades that are closer to roads, which makes those parts of buildings unfit for residential purposes. Courtyars, the last parts of buildings and roofs, are least impacted by traffic noise. They are the safest places to be used for residential purposes and research has also shows that the height of the building is not an effective means of reducing traffic noise in the upper parts of the building [16].

Noise pollution is not less harmful than any other form of pollution. Longer exposure to high noise can cause temporary or permanent mental and physical damage to human body functions [17-20]. Individual sensitivity to noise is an important factor in evaluating the effects of disturbing noise [21]. Results of long-term study have shown that about $10 \%$ of the population is more sensitive to noise, especially children younger than 6 and adults older than 65 . Women are more sensitive than men in their middle age. Individual sensitivity is affected by neurovegetative condition and the vascular system [22-24], some virus infections, use of alcohol and tobacco, and professional exposure to neurotoxin materials $[25,26]$.

Noise intensity of $35 \mathrm{~dB}(\mathrm{~A})$ extends a time-needed to fall asleep, and this is only shallow sleep. A noise level of 45 $\mathrm{dB}(\mathrm{A})$ causes spontaneous awakening, and awakening as a result of such derangement occurs during sleep, whereas the strength of $50 \mathrm{~dB}(\mathrm{~A})$ or more prevents a person from having any rest. It can be concluded that the permanent effect of noise decreases human life expectancy by $8-10$ years [27].

It is difficult to have communication in a noisy environment due to the voice communication masking effect [28]. A frequency range of $300 \mathrm{~Hz}$ to $3 \mathrm{kHz}$ is especially important for understanding one's speech, and this is the range of the majority of the sound energy of noise pollution [26].

The noise level present in the environment is not high enough to damage hearing, but it causes a whole range of audio and extra audio effects [26]. Noise has become a very serious problem due to urban development, where transport is a necessity [29]. Industrial society depends on mechanical transport for efficient distribution and exchange of people and goods, for schools, shops, factories, and many other sectors [30].

Based on questionnaire research, it was determined that in German towns with over 5,000 people, $14-16 \%$ are endangered by road traffic noise. In towns with 5,000 up to 20,000 inhabitants this percentage is $17-18 \%$, in towns of 20,000 to 100,000 inhabitants it is $19-25 \%$, while in cities with over 100,000 inhabitants, $22-33 \%$ of the population feels a psychophysical burden and anxiety [28].

The main focus of this paper is on road traffic noise from cars, vans, busses, and motorbikes. Each of these creates a specific form of noise [31]. The causes of the problem are engines, internal audio, brakes, and tires. Some responsibility is on drivers, who should take care of their car's condition. For example, car brakes should not squeak. Drivers also need to be aware that their cars certainly produce noise, which should lead them to driving without causing inconvenience to other people, for example, avoiding a "harsh" ride in quiet residential areas and avoiding night driving, etc.

The aim of this paper is to determine through review, analysis, and systematization of results on the intensity of noise in the city of Novi Sad whether this parameter is within the permissible values for the intensity of noise during the day and night, and if it is in accordance with the legal provisions of national norms of permissible noise levels, or whether this parameter influences the environmental degradation of man. On the basis of these results, the goal is to identify and map more suitable and less suitable areas for urban life. Another goal of this work is to find solutions and list suggestions for decreasing the level of noise.

\section{Materials and Methods}

\section{Study Area}

Novi Sad is the second largest city in the Republic of Serbia and the largest city of the Autonomous Province of Vojvodina. Geographic location is $19^{\circ} 50^{\prime} 41^{\prime \prime}$ eastern longitude and $45^{\circ} 15^{\prime} 18^{\prime \prime}$ northern latitude. It stands on the banks of the River Danube south of the region Bačka; altitude of 76 to $82 \mathrm{~m}$. The municipality land area is about $702.7 \mathrm{~km}^{2}$, and it has population of 360,000 and 512 inhabitants $/ \mathrm{km}^{2}$ according to the last census conducted in 2011 [32]. Due to favorable geographical location, Novi Sad represents the crossroad of the main inland and waterways in Vojvodina, with numerous highways and railroads, and some of them are of international importance [33].

The development of Novi Sad as the administrativepolitical, industrial and economic center, due to intensive housing and other forms of construction work, dictates needs for public utilities development where urban and suburban public transportation has a crucial role. Ongoing development of urbanization and industrialization is required by daily travelling business people, students, and the entire population of the village and the surrounding area. For urban public transport, buses, which were introduced in 1958, are still the main mean of transport together with taxis. Intensive urbanization and expansion of the city has increased the number of cars and the unsolved problems of parking, traffic jams, and residential noise have been the biggest urban problems for the city of Novi Sad [33]. Tax exemption on the import of new and used vehicles from Western European countries has contributed to the increase in the number of vehicles in Novi Sad and to an increase in ecological problems.

\section{Data and Processing}

Residential noise monitoring is one of the indicators for environmental quality. Monitoring of noise levels in the city is determined by noise source and the results are 
Table 1. Permissible level of road traffic noise in the intended zone [41].

\begin{tabular}{|l|c|c|}
\hline \multirow{2}{*}{ Intended zone } & \multicolumn{2}{|c|}{$\begin{array}{c}\text { Permitted level } \\
\text { of Residential } \\
\text { noise (dB(A)) }\end{array}$} \\
\cline { 2 - 4 } & Day & Night \\
\hline I Areas for recreation, hospitals, large parks & 50 & 40 \\
\hline $\begin{array}{l}\text { II Tourist zone, small and rural settlements, } \\
\text { camps and school zones }\end{array}$ & 50 & 45 \\
\hline III Only residential blocks & 55 & 45 \\
\hline IV Business and residential blocks, playgrounds & 60 & 50 \\
\hline $\begin{array}{l}\text { V City center, highway, motorway, and city } \\
\text { road zones }\end{array}$ & 65 & 55 \\
\hline VI Industrial zone & 70 & 70 \\
\hline
\end{tabular}

obtained on the basis of whether it is possible to take possible measures in terms of more appropriate and humane urban planning. Measuring residential noise in the area of Novi Sad has constantly been applied since 1980 .

Evaluation of road traffic noise in the environment is carried out according to standard methodology in accordance with valid legal basis. The methods used in measuring road traffic noise in the environment are defined by the following standards:

1. SRPS ISO 1996-1:2008 [34]

2. SRPS ISO 1996-2:2008 [35]

3. SRPS ISO U.J6. 205:2007 [36]

4. SRPS ISO U.J6.090:1992 [37]

A series of laws in Serbia treat in different ways environmental issues, in whole or particular aspects, such as: food, water, air, soil, etc. [38-43]. This is an attempt to create a solid legal basis in accordance with law and bylaw acts that would create for all subjects of social life obligations in dealing with everyday life and work, and the basics of responsibility and the penalty for violations of these regulations. Unfortunately, law and bylaw acts by which the level of environmental noise is regulated are not obeyed, and noise is often considered to be a marginal problem.

All obtained values of road traffic noise are applied with applicable standards, which regulate permitted levels in certain areas. Values range from $50 \mathrm{~dB}(\mathrm{~A})$ during the day and $40 \mathrm{~dB}(\mathrm{~A})$ during the night in the areas of recreation, parks and hospitals to $70 \mathrm{~dB}(\mathrm{~A})$ (during the day and night) in purely industrial areas of the city (Table 1).

Raw data from the Institute for Public Health of Vojvodina - Department of Residential Hygiene were obtained for the analysis of noise in Novi Sad [26]. Data were obtained by measuring the noise intensity on roads in the residential, school, and sporting-recreational zones where the speed limit is 40 and $50 \mathrm{~km} / \mathrm{h}$.

The measuring points do not include the industrial zone, therefore maximum daily measured level of road traffic noise value is $65 \mathrm{~dB}(\mathrm{~A})$ during the day and $55 \mathrm{~dB}(\mathrm{~A})$ during the night. In accordance with the regulations of
Directive 2002/49/EC [5] and the act of noise indicators, limited values, methods for estimation of noise indicators, disturbance and harmful noise effects in the environment [38], and road traffic noise in the environment was measured over a three-day period (day 06:00-18:00, evening 18:00-22:00, and night 22:00-06:00).

The system used to measure the noise level in the environment consists of:

1. Brüel \& Kjær transmitting noise analyzer type 2250

2. BZ5503 - utility software for hand-held analyzers

3. Softver Noise Explorer Type 7815, version 4.15

At all 18 measuring points the measuring was done in the same way, setting a microphone at a distance of at least $5 \mathrm{~m}$ from the road and $1.5 \mathrm{~m}$ above the ground.

The percentage of "highly annoyed" persons (HA) due to road traffic noise was calculated with the equation:

$$
\begin{gathered}
\mathrm{HA}[\%]=0.5118 \cdot\left(\mathrm{L}_{\mathrm{den}}-42\right)-1.436 \cdot 10^{-2} \cdot\left(\mathrm{L}_{\mathrm{den}}-42\right)^{2} \\
+9.868 \cdot 10^{-4} \cdot\left(\mathrm{L}_{\mathrm{den}}-42\right)^{3}
\end{gathered}
$$

We used software package STATISTICA 12. Obtained data were processed by the use of descriptive statistical analysis, which represents a method for determinig certain parameters relevant for the description of behaviour of observed characteristics. The following indicators were determined: average value $(\overline{\mathrm{X}})$, extreme values (minimum and maximum), median (Me), modus, standard deviation $(\sigma)$, variation coefficient $(\mathrm{Cv})$ [44].

In order to determine correlation between the intensity of noise and the number of vehicles, Spearman's correlation coefficient was calculated using the formula:

$$
r_{s}=1-\frac{6 \cdot \sum d_{i}^{2}}{n^{3}-n}
$$

...where $d$ represents the difference in values of ranks of two observed variables, and $n$ is the number of different series [44].

The linear regression model has been derived for the analysis of noise intensity trend in the city of Novi Sad for the past 20 years.

ArcGIS 9.2 software by ESRI Company has been used in the paper. Maps were made in GSC_WGS_1984 Geographic Coordinate System, D_WGS_1984 Date, with Prime Meridian Greenwich. The process of making noise maps of Novi Sad was done in the following stages: collecting material, database building, and digitization. Use of geographic information system (GIS) and its associated databases is an efficient medium for showing spatial relationship, where standardization personal data and methods and their harmonization with European standards are significant. GIS is a system that provides new views and interpretations of its raw and united data, which are sometimes hard to correlate without spatial dimensions [45]. The idea of connecting "raw" data with real points and areas (i.e. coordinates within GIS) has contributed to map visualization. 
Table 2. Measuring points, the value of daylight and nighttime noise levels, and the percentage of highly vulnerable populations, 2010 [26].

\begin{tabular}{|c|c|c|c|c|c|}
\hline $\begin{array}{l}\text { Measuring } \\
\text { point }\end{array}$ & Location & $\begin{array}{c}\mathrm{L}_{\text {day }} \\
\mathrm{dB}(\mathrm{A})\end{array}$ & $\begin{array}{c}\mathrm{L}_{\text {night }} \\
\mathrm{dB}(\mathrm{A})\end{array}$ & $\% \mathrm{HA}$ & Zone \\
\hline 1. & $\begin{array}{l}\text { Corner of Subotički Boulevard and Đorđe Magarašević } \\
\text { street }\end{array}$ & 68 & 59 & 22.6 & Residential \\
\hline 2. & Ivan Gundulić elementary School & 65 & 59 & 14.1 & School \\
\hline 3. & Car Dušan Street & 71 & 63 & 24.1 & Residential \\
\hline 4. & Sajmište Sports Center & 66 & 58 & 16.0 & Sport-recreative \\
\hline 5. & Corner of Partizanska and Đorđe Zličić streets & 73 & 64 & 26.8 & Next to traffic roads \\
\hline 6. & Car Lazar Boulevard & 68 & 60 & 23.5 & Next to traffic roads \\
\hline 7. & Maksim Gorki Street & 69 & 61 & 23.9 & City centre \\
\hline 8. & Uspenska Street & 68 & 60 & 23.4 & City centre \\
\hline 9. & Svetozar Marković Gymnasium & 65 & 57 & 21.5 & School \\
\hline 10. & Corner of Jovan Dučić Boulevard and Bata Brkić Street & 65 & 56 & 10.6 & Residential \\
\hline 11. & Corner of Kornelije Stanković and Joakim Vujić streets & 69 & 61 & 22.4 & Next to traffic roads \\
\hline 12. & Kej žrtava racije & 70 & 62 & 27.3 & City centre \\
\hline 13. & Oslobođenja Boulevard & 69 & 62 & 22.2 & Next to traffic roads \\
\hline 14. & Corner of Futoški Put and Knez Miloš Boulevard & 69 & 60 & 17.6 & Next to traffic roads \\
\hline 15. & Jovan Dučić Elementary School & 66 & 58 & 21.1 & School \\
\hline 16. & Corner of Vršačka and Jovan Popović streets & 64 & 57 & 21.8 & Residential \\
\hline 17. & Rumenačka Street & 69 & 62 & 23.1 & Next to traffic roads \\
\hline 18. & $\begin{array}{l}\text { Corner of Oslobođenja Boulevard and Narodni Front } \\
\text { Street }\end{array}$ & 69 & 62 & 24.7 & Next to traffic roads \\
\hline
\end{tabular}

\section{Results and Discussion}

During the analysis, average annual and monthly residential noise values at the measuring points in the city were tracked and analyzed to the maximal values recorded during the tracking period compared to the values regulated by the Law on Noise Protection [41] and the regulation on measuring method of noise and the reporting extent of measured noise [42].
Results of monitoring residential noise from 1991 to 2010 (Fig. 1) showed that the highest road traffic noise level was recorded at the beginning of the monitoring period during 1991 and 1992 in the amount of $82 \mathrm{~dB}(\mathrm{~A})$. Since that period average annual road traffic intensity value has been decreasing and it has not risen above $70 \mathrm{~dB}(\mathrm{~A})$ since 1998. The lowest value was recorded at the end of the monitoring period $(2005,2008$, and 2010) at $68 \mathrm{~dB}(\mathrm{~A})$. However, it has been rising above limited value of $65 \mathrm{~dB}(\mathrm{~A})$ for 3 to 17

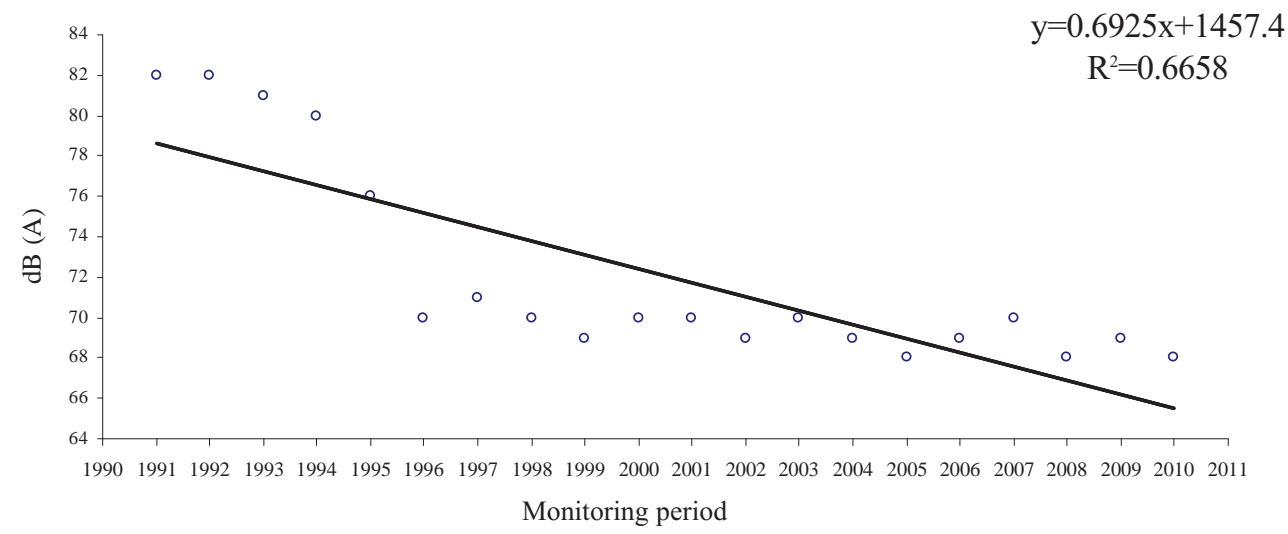

Fig. 1. Noise sound pressure levels in the city of Novi Sad from 1991 to 2010. 
Table 3. Descriptive statistical analysis of daily and night noise intensity in Novi Sad in 2010.

\begin{tabular}{|c|c|c|c|c|c|c|}
\hline & Valid N & Min & Max & $\overline{\mathrm{X}}$ & $\sigma$ & $\mathrm{C} v$ \\
\hline $\mathrm{L}_{\text {day }}$ & 18 & 64 & 73 & 67.94 & 2.36 & 3.48 \\
\hline $\mathrm{L}_{\text {night }}$ & 18 & 56 & 64 & 60.05 & 2.26 & 3.76 \\
\hline
\end{tabular}

$\mathrm{dB}(\mathrm{A})$. However, the linear trend observed over 20 years is declining. Determination coefficient $\left(\mathrm{R}^{2}=0.6658\right)$ is not high, meaning that $66.58 \%$ of the connection is explained by linear regression model. Renewal of the public transport company fleet and the presence of newer vehicles in Novi Sad which produce less noise have resulted in a decrease in the noise intensity in the observed period. Ecological awareness of the population and mass usage of bicycles have also contributed to a decrease in noise intensity and decrease in pollution and in the traffic jam.

Measuring results of road traffic noise in 2010 at 18 measuring points (Table 2) allow more precise analysis, on the basis of which could suggest certain measures to reduce road traffic noise.

Results of descriptive statistical analysis of daily and night noise intensity in the city of Novi Sad in 2010 are shown in Table 3. During 2010 minimal annual average daily value of equivalent road traffic noise level $\left(\mathrm{L}_{\text {day }}\right)$ in the environment in the city of Novi Sad was determined at measuring point No. 16 in the amount of $64 \mathrm{~dB}(\mathrm{~A})$, and maximum average daily value of equivalent road traffic noise level was determined at measuring point No. 5 in the amount of $73 \mathrm{~dB}(\mathrm{~A})$. Average annual value of daily equivalent road traffic noise level in the city of Novi Sad was in the amount of $67,94 \mathrm{~dB}(\mathrm{~A})$ in 2010 .

Compared to total determined amount (216) of average monthly equivalent, day road traffic noise level in the environment of the city of Novi Sad was 40 (18.52\%) in accordance with and $176(81.48 \%)$ over the limited amount, according to the Act of National Normative of Permitted Daytime Noise Levels of $65 \mathrm{~dB}(\mathrm{~A})$ during 2010.
During 2010 minimal annual average night value of equivalent road traffic noise level $\left(\mathrm{L}_{\text {night }}\right)$ in the environment in the city of Novi Sad was determined at measuring point No. 10 in amount of $56 \mathrm{~dB}(\mathrm{~A})$, and maximum annual average night value of equivalent road traffic noise level was determined at measuring point No. 5 the in amount of 64 $\mathrm{dB}(\mathrm{A})$. Average annual night value of equivalent road traffic noise level in the city of Novi Sad was in amount of $60.05 \mathrm{~dB}(\mathrm{~A})$ in 2010.

Compared to total determined amount (72) of average monthly equivalent, night road traffic noise level in the environment of the city of Novi Sad was 4 (5.56\%) in accordance with and 68 (94.44\%) over the limited amount, according to the act of national normative of permitted noise level for night of $55 \mathrm{~dB}(\mathrm{~A})$.

Road traffic noise on some locations in the first place depends on traffic type, share of heavy traffic, slope of the street, street type, height and house density, surface, vehicle speed, distance of traffic lights and crossroads in general, general technical condition of traffic, etc. At the location, assuming the same mode of traffic, road traffic noise in local environment measuring point depends on several parameters, first of all period of the day, day of the week, season, etc.

Measuring the noise level of daily traffic in Novi Sad was also accompanied by a number of heavy and light vehicles and motorcycles in 2010 (Fig. 2). It was found that the average frequency value of light passing vehicles was 419 vehicles/15 minutes, average frequency value of heavy passing vehicles was 17 vehicles/15 minutes, and average frequency value of motorcycle passing was 3 motorcy-

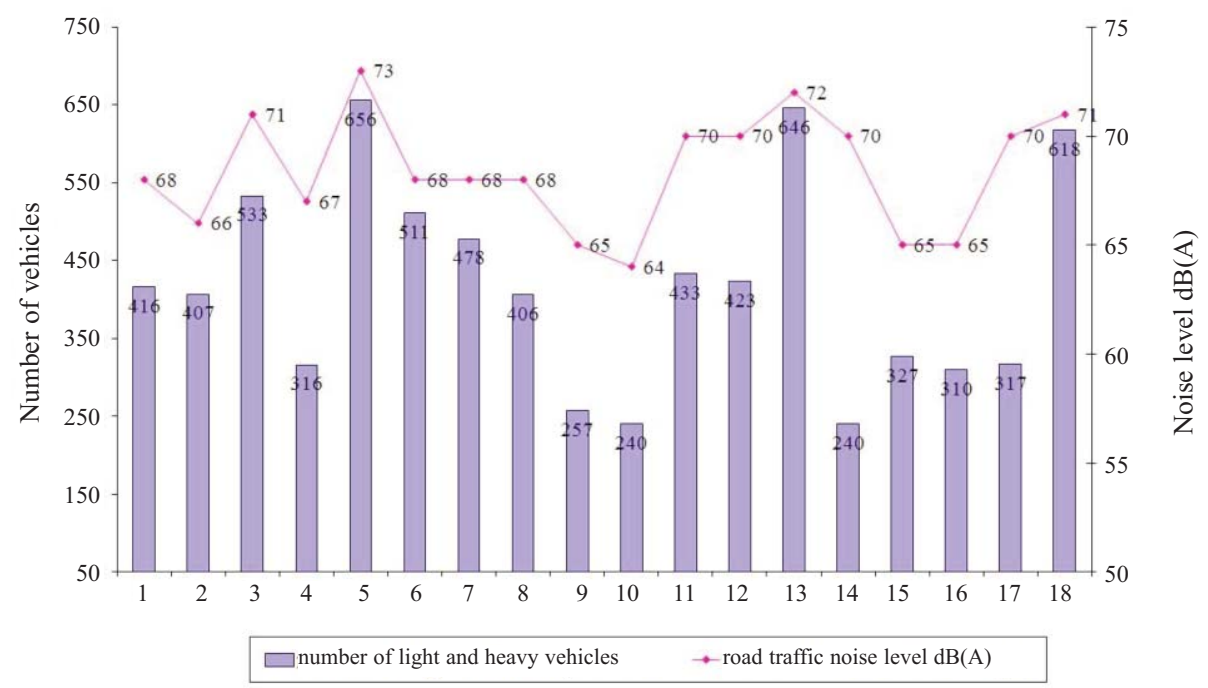

Fig. 2. Frequency level of passing of light and heavy vehicles and daily road traffic noise levels. 
cles/15 minutes. It is characteristic for vehicles (passenger cars) to make noise at frequencies between 250 and $100 \mathrm{~Hz}$, while for heavy vehicles (trucks, busses) it is characteristic to make noise at frequencies between 500 and $400 \mathrm{~Hz}$. Mopeds and motorcycles make noise at very low frequencies (30-200 Hz) [26]. These results are the annual average based on 648 daily measurements during 2010 in the 15minute period.

Statistical analysis shows that the noise level is in a strong positive correlation (Spearman Rank Order Correlations, $r_{s}=0.73$ ) with a number of light and heavy passing vehicles (Fig. 3).

Road traffic noise level usually exceeds values permitted for certain city zones. The highest noise intensity has been recorded on measuring points on boulevards with heavy traffic.

In zones along the city road traffic (measuring points 5 , $6,11,13,14,17$, and 18) level of noise in most cases is higher than permitted standards from $1 \mathrm{~dB}(\mathrm{~A})$ to $8 \mathrm{~dB}(\mathrm{~A})$ during the day and from $1 \mathrm{~dB}(\mathrm{~A})$ to $9 \mathrm{~dB}(\mathrm{~A})$ during the night (Figs. 4 and 5).

Particularly concerning is the level of road traffic noise which exceeds permitted levels in school and residential zones. In school zones (measuring points 2, 9, and 15) the road traffic noise level is higher by $12 \mathrm{~dB}(\mathrm{~A})$ to $16 \mathrm{~dB}(\mathrm{~A})$ related to permitted level of road traffic noise per-use zones (Table 1). In the residential zone (measuring points $1,3,10$, and 16) the level of road traffic noise is higher by $9 \mathrm{~dB}(\mathrm{~A})$ to $16 \mathrm{~dB}(\mathrm{~A})$ than permitted standards during the day and by $11 \mathrm{~dB}(\mathrm{~A})$ to $18 \mathrm{~dB}(\mathrm{~A})$ during the night. In the city center (measuring points 7,8 , and 12) the level of road traffic noise is higher by $9 \mathrm{~dB}(\mathrm{~A})$ to $5 \mathrm{~dB}(\mathrm{~A})$ than permitted standards during the day and by $5 \mathrm{~dB}(\mathrm{~A})$ to $7 \mathrm{~dB}(\mathrm{~A})$ during the night. The city has no measuring points in the walking zone, therefore the noise registered in the center is traffic noise; measuring points are near the roads that pass through the city center.

All population groups of different age, gender, and health are exposed to the source of road traffic noise in urban environment $[46,47]$. In the urban environment there is a great number of people exposed to noise higher than 65 $\mathrm{dB}(\mathrm{A})$ with traffic of at least 500 motor vehicles an hour (of which at least $15 \%$ are heavy vehicles). It can be noticed that the most endangered population in Novi Sad is in the city center $(27.3 \% \mathrm{HA})$ and next to city roads $(17.6 \%$ $27.6 \%$ HA).

Based on the results mentioned in this paper it is recorded that noise intensity in the whole period and on almost all measuring points is higher than what is regulated and permitted. Given these results and comparing them with per-
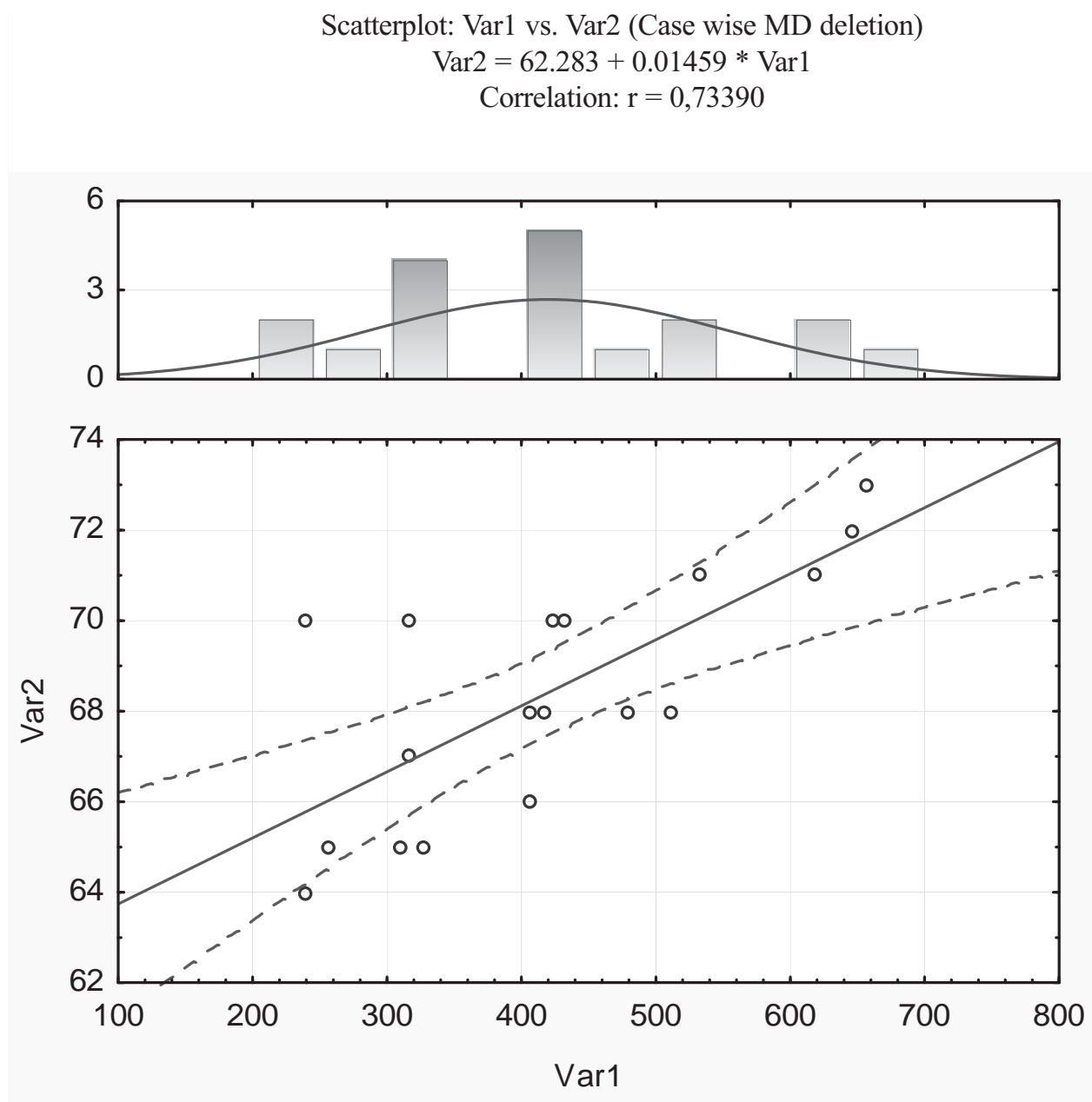

$\mathrm{X}: \operatorname{Var} 1$

$\mathrm{N}=18$

Mean $=418.555556$

Std.Dv. $=133.824829$

Max. $=656.000000$

Min. $=240.000000$

Y: $\operatorname{Var} 2$

$\mathrm{N}=18$

Mean $=68.388889$

Std.Dv. $=2.659918$

Max. $=73.000000$

Min. $=64.000000$

Fig. 3. Scatterplot matrix for number of vehicles (Var1) and noise intensity in $\mathrm{dB}(\mathrm{A})$ (Var2).

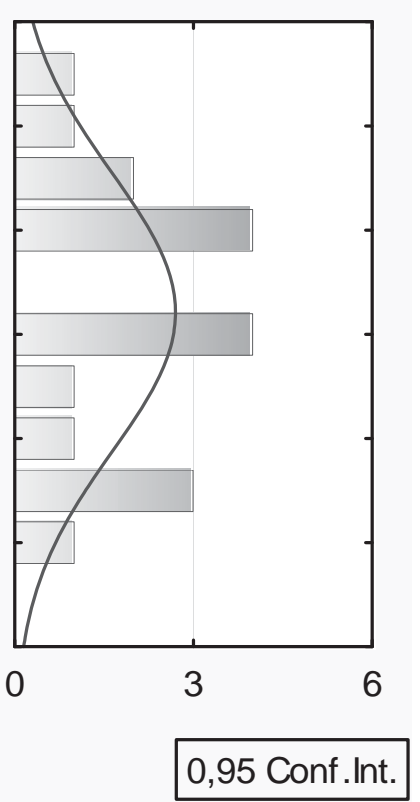




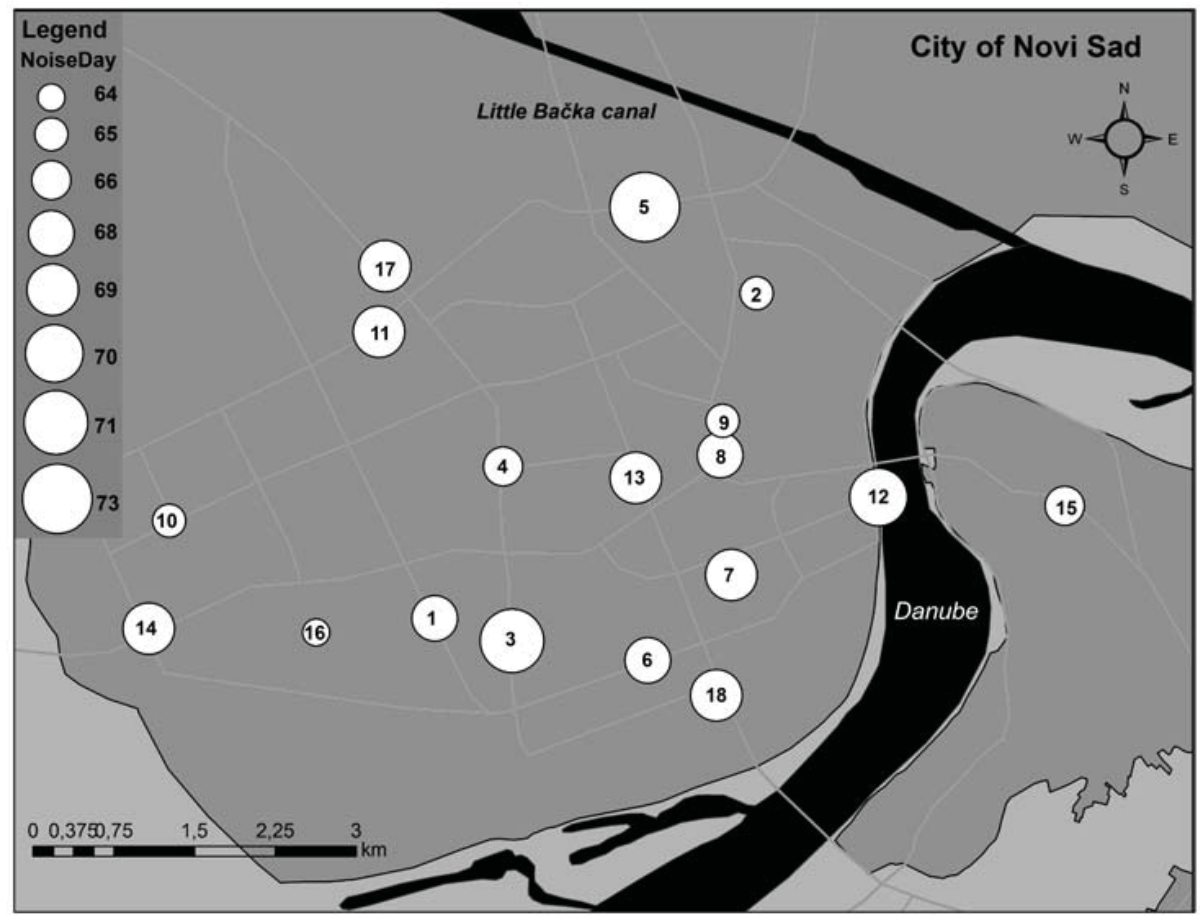

Fig. 4. Road traffic noise sound pressure levels in the city of Novi Sad during the day.

mitted values for the day and the night, it is clear that there are real conditions that are harmful to the human body and overall life satisfaction.

Noise protection is carried out in various ways. Sound barriers are commonly used for traffic noise. Absorbant materials used for this purpose mostly have broadband and non-selective adsorption properties. Modern materials technology opens up the possibility of using composite structures with optimal absorption and acoustic insulation prop- erties. Accurate knowledge of the spectral characteristics of the source, due to the use of composite materials, provides achieving the required results in reducing the noise level permitted to measure with saving of material and space.

Numerous functions of green areas are evidence of their immense importance in any modern settlement. Their influence on the improvement of quality of the city environment is proportional to their size, distribution, and general quality. However, it is not enough to say that the benefits of

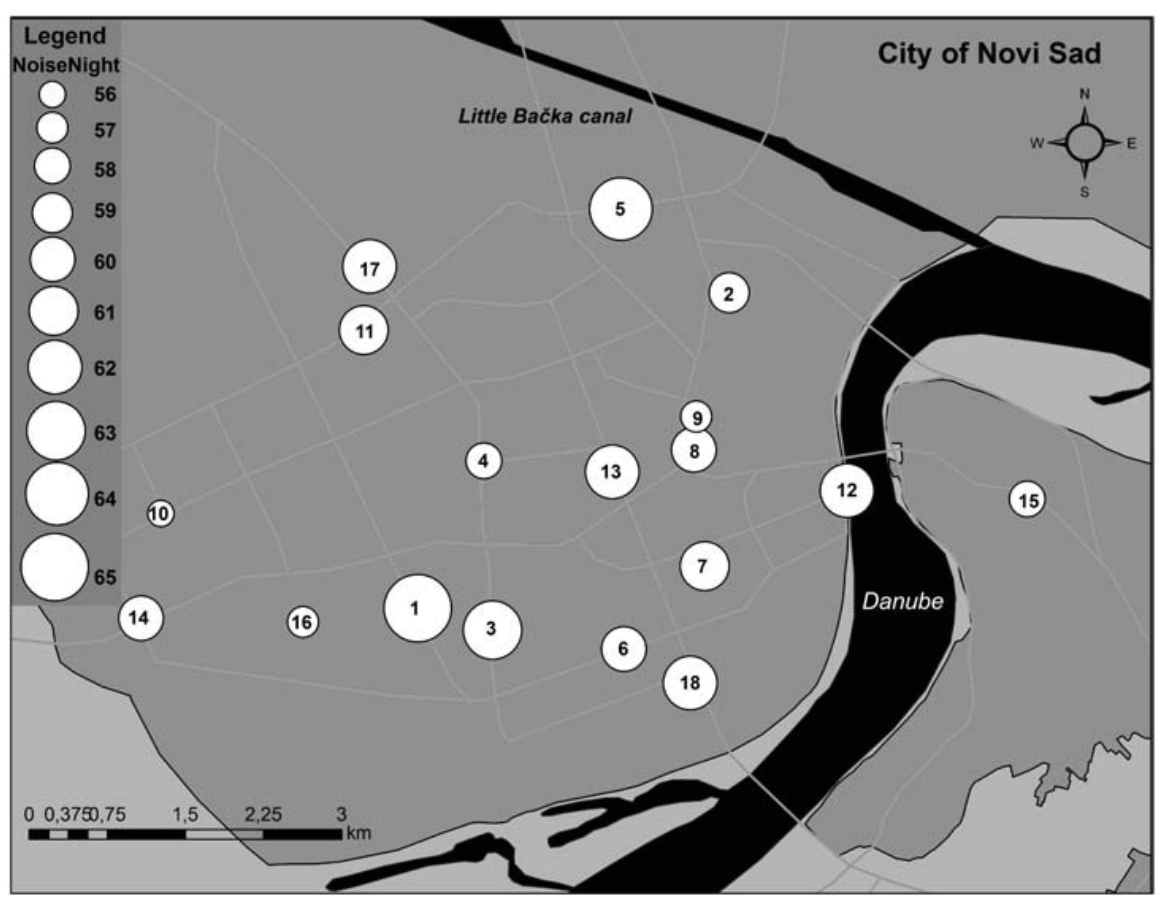

Fig. 5. Road traffic noise sound pressure levels in the city of Novi Sad during the night. 
green areas are large: they have become one of the main structural elements of each urban area. Because of this, the city's green areas in almost all the major cities can significantly ease lives of inhabitants, and the simplicity and economy of urban green makes this possibility quite valuable.

In major urban areas, the noise level can be reduced by building wide boulevards with adequate construction of buildings and good organization of traffic [48]. Raising green spaces that reduce noise has been shown as an effective protection against noise. The intensity of the reduction depends on the physical properties of sound, dendrology composition, height, width, and location of green barriers in relation to the noise source and the receiver [49-51]. It is recommended to raise the green belt between the street and pavement width of 10-50 m, where trees and shrubs will be planted. Such a green belt can reduce noise by $8-10 \mathrm{~dB}(\mathrm{~A})$. Research has shown that the crowns of deciduous trees absorb about $25 \%$ of sound energy, which is especially visible in streets without trees with average heavy traffic, where noise is almost five times louder when compared with a green street [52].

It has been emphasized in previous studies [53] that for "optimal" protection against noise, a green bar should have a width of 20-35 m, as narrow strips are less affected by noise, and a wider strip practically does not give any additional effect. With more dense trees and bushes planted in the protective bar against noise and the larger the area of green mass of vegetation in it, the bigger effect is in reducing sound energy falling on the surface. The combination of hedges with trees also gives a positive effect in reducing noise, and thick green plantations of good quality (combination of tree and shrub) reduce the overall noise level of 14 to $15 \mathrm{~dB}(\mathrm{~A})$ [54].

Dendrological deciduous species that are good sonic insulators are: Viburnum lantana, Viburnum rhytiphyllum, Ilex aquifolium, Catalpa bignonioides, Carpinus betulus, Tilia sp., and Quercus sp. Dendrological conifer species are recommended for protection against noise throughout the year. Particularly useful are: Pinus nigra, Pinus sylvestris, Pseudotsuga menziesii, Picea sp., and Abies alba [55]. Unfortunately, in many streets in Novi Sad, especially in the old city center, physical qualities for planting greenbelts, which would protect from noise, do not exist due to the narrow streets and the closeness of buildings to the road. A somewhat better situation is at wide boulevards in the city suburbs, where the possibilities for this type of protection exist but are not used.

Another way of reducing the harmful effects of noise is the availability of green spaces. Some previous studies found that high neighborhood quality in terms of attractive appearance, and the presence of parks and green spaces lowered dissatisfaction with traffic noise to a significant degree [56]. Good availability to nearby green areas furthermore can enhance the positive effects of access to a quiet side, where these nearby green areas also play an important role in moderating the adverse effects of traffc noise $[57,58]$. Unfortunately, in the last couple of years the green areas in Novi Sad have decreased. Parking places, residential buildings, and malls are emerging, absorptive surface is decreasing, and the condition of the environment in the city is deteriorating.

An interdisciplinary approach and the application of upto-date acoustic methods of measuring and predicting noise in the environment ensure noise reduction. System management of environmental noise represents a complete set of instruments known as "4M": measuring, monitoring, mapping, and management [26].

- Measuring - the use of acoustic measuring in order to accurately characterize the observed noise sources in the environment

- Monitoring - using unsupervised methods of acoustic measuring in order to provide more accurate monitoring time variability of the observed noise sources

- Mapping - using the instrument noise maps and action plans as a starting instrument in establishing the management system of environmental noise

- Management - the use of all instruments in one whole, lively, interactive system

\section{Conclusion}

Noise pollution in Novi Sad is not recognized and accepted as an environmental problem as much as it should be. It has been scientifically proven that noise is potentially dangerous for health, communication, productivity of inhabitants; and therefore life quality. Nevertheless, this problem has been marginalized in the pile of other urbanproblems.

Analysis of the measuring results points to several facts. It is recorded that in all zones, both day and night levels exceed the permitted values. Such large overdrafts are the result of unregulated traffic and the absence of measurements that could at least partially reduce noise levels. On the other hand, the night values indicate that harassment of citizens is caused mostly by high traffic noise levels in a period planned for relaxation.

During the analyzed period in zones along the city roads, traffic noise levels in most cases were higher than permitted by $1 \mathrm{~dB}(\mathrm{~A})$ to $8 \mathrm{~dB}(\mathrm{~A})$ during the day, and from $1 \mathrm{~dB}(\mathrm{~A})$ to $9 \mathrm{~dB}(\mathrm{~A})$ during the night. Particularly worrying is the fact that noise levels exceed the level of the school and residential zones. In school zones, the noise level is increased by $12 \mathrm{~dB}(\mathrm{~A})$ to $16 \mathrm{~dB}(\mathrm{~A})$ compared to the permitted noise levels. In residential zones, the noise level is increased by $9 \mathrm{~dB}(\mathrm{~A})$ to $16 \mathrm{~dB}(\mathrm{~A})$ during the day and 11 $\mathrm{dB}(\mathrm{A})$ to $18 \mathrm{~dB}(\mathrm{~A})$ during the night. In the city center, and business and residential zones, the noise level is increased by $3 \mathrm{~dB}(\mathrm{~A})$ to $5 \mathrm{~dB}(\mathrm{~A})$ during the day and by $5 \mathrm{~dB}(\mathrm{~A})$ to 7 $\mathrm{dB}(\mathrm{A})$ during the night.

This alarming situation of noise pollution demands strategic planning and systematic work of everyone involved to reach the goal, which is permitted noise levels in the city zones. Having in mind that traffic noise has the largest impact on creating residential noise, the first thing to be done is to propose measurements aimed at traffic regulation, and then to choose quieter city zones for hospitals, schools, university facilities, etc. in future planning. 
When the fact that noise causes harmful effects to human health, mood and life satisfaction is taken into consideration, and it is clear that it is necessary to protect people. Protective measures can be taken in three ways:

1. Preventing noise at the source

2. Noise reduction by distancing from sources (using bisecting road transport noise)

3. Use of personal protective equipment against noise Since it is impossible to reduce the number of vehicles in traffic and the frequency of their use, some preventive measures could be taken to protect human health. In order to reduce residential noise it is necessary to:

- Constantly monitor residential noise levels in the territory of the city of Novi Sad

- Ensure proper urban planning for the city

- Control the noise levels emitted by motor vehicles during technical control

- Constantly monitor residential noise levels emitted by motor vehicles

- Expand the network of streets with automatic traffic control and synchronization of traffic lights

- Increase the number of measuring points in the city

- Reallocate measuring points to determine the day and the night residential noise levels in order to obtain average monthly authoritative day and night residential noise levels in the city

- Planned greening of public spaces

- Provide easy access to parking areas

- Provide acoustic insulation of buildings

- Developing action plans to reduce noise levels in the city of Novi Sad, in accordance with Directive 2002/49 and the existing legal basis, the main goal of which is to reduce noise levels in the environment in order to reduce the number of people disturbed by noise.

\section{Acknowledgements}

The authors would like to express their sincere thanks to the Ministry of Education, Science and Technological Development of the Republic of Serbia (grant No. 176020) and the Provincial Secretariat for Science and Technological Development of the Vojvodina Province (grant No. 114451-2644/2012-01), for their financial support.

\section{References}

1. RAIMBAULT M., DUBOIS D. Urban soundscapes: Experiences and knowledge. Cities, 22, (5), 339, 2005.

2. WORLD HEALTH ORGANIZATION. Burden of disease from environmental noise Quantification of healthy life years lost in Europe, WHO European Centre for Environment and Health. Bonn Office, 2011. Available on: http://www.who.int/quantifying_ehimpacts/publications/ e94888.pdf

3. WORLD HEALTH ORGANIZATION Environmental health inequalities in Europe, WHO European Centre for Environment and Health. Bonn Office, 2012. Available on: http://www.euro.who.int/_ data/assets/pdf file/0010/15796 9/e96194.pdf
4. GAN W. Q., MCLEAN K., BRAUER M., CHIARELLO S. A., DAVIES H. W. Modeling population exposure to community noise and air pollution in a large metropolitan area. Environ. Res., 116, 11, 2012.

5. EUROPEAN COMMISSION. Directive 2002/49/EC of the European Parliament and of the Council of 25 June 2002 relating to the assessment and management of environmental noise. Official J. Eur. Commun. L189, 12-25, 2002.

6. LI B., TAO S., DAWSON R.W. Evaluation and analysis of traffic noise from the main urban roads in Beijing. Appl. Acoust., 63, 1137, 2002.

7. BRAINARD J.S., JONES A.P., BATEMAN I.J., LOVETT A.A. Exposure to environmental urban noise pollution in Birmingham, UK. Urban Stud., 41, (13), 2581, 2004.

8. LI B., TAO S. Influence of expanding ring roads on traffic noise in Beijing City. Applied Acoustics, 65, 243, 2004.

9. GEURS K.T., WEE B.V. Ex-post evaluation of thirty years of compact urban development in the Netherlands. Urban Stud., 43, (1), 139, 2006.

10. ALLEN R.W., DAVIES H., COHEN M.A., MALLACH G., KAUFMAN J.D., ADAR S.D. The spatial relationship between traffic-generated air pollution and noise in 2 US cities. Environ. Res., 109, 334, 2009.

11. AUSEJO M., RECUERO M., ASENSIO C., PAVON I., LOPEZ J.M. Study of precision, deviations and uncertainty in the design of the strategic noise map of the macrocenter of the city of Buenos Aires, Argentina. Environ. Model. Assess., 15, 125, 2010.

12. ROSS Z., KHEIRBEK I., CLOUGHERTY J.E., ITO K., MATTE T., MARKOWITZ S., EISL H. Noise, air pollutants and traffic: Continuous measurement and correlation at a high-traffic location in New York City. Environ. Res., 111, 1054, 2011.

13. EHRAMPOUSH M. H., HALVANI G. H., BARKHORDARI A., ZARE M. Noise Pollution in Urban Environments: a Study in Yazd City, Iran. Pol. J. Environ. Stud., 21, (4), 1095, 2012.

14. ADAMS M., COX T., MOORE G., CROXFORD B., REFAEE M., SHARPLES S. Sustainable soundscapes: noise policy and the urban experience. Urban Stud., 43, (13), 2385, 2006.

15. BARANZINI A., RAMIREZ J.V. Paying for quietness: the impact of noise on Geneva rents. Urban Stud., 42, (4), 633, 2005.

16. PAMANIKABUD P., TANSATCHA M. 3D analysis and investigation of traffic noise impact from a new motorway on building and surrounding area. Appl. Acoust., 71, 1185, 2010.

17. ATKINSON R. Ecology of sound: the sonic order of urban space. Urban Studies, 44, (10), 1905, 2007.

18. QUIS D. Exposure to nocturnal road traffic noise: Sleep disturbance and its after effects. Noise Health, 1, (4), 11, 1999.

19. BELOJEVIĆ G., SARIĆ-TANASKOVIĆ M. Prevalence of arterial hypertension and myocardial infarction in relation to subjective ratings of traffic noise exposure. Noise Health, $\mathbf{4}$, (16), 33, 2002.

20. PETERSON E.A., AUGENSTEIN J.S., TANIS D.C., AUGENSTEIN D.G. Noise Raises Blood Pressure without Impairing Auditory Sensitivity. Science, 211, (4489), 1450, 1981.

21. PARKES A., KEARNS A., ATKINSON R. What makes people dissatisfied with their neighbourhoods? Urban Stud., 39, (13), 2413, 2002 
22. BABISCH W. Traffic noise and cardiovascular disease: epidemiological review and synthesis. Noise Health, 2, (8), 9, 2000.

23. NEUS H., BOIKAT U. Evaluation of traffic noise-related cardiovascular risk. Noise Health, 2, (7), 65, 2000.

24. CHANG T.Y., LAI Y.A., HSIEH H.H., LAI J.S., LIU C.S. Effects of environmental noise exposure on ambulatory blood pressure in young adults. Environ. Res., 109, 900, 2009.

25. ALLEN R.W., ADAR S.D. Are both air pollution and noise driving adverse cardiovascular health effects from motor vehicles? Environ. Res., 111, 184, 2011.

26. Ecological Bulletin. City of Novi Sad: City Administration for Environmental Protection \& Institute for Public Health of Vojvodina - Department of Residential Hygiene, 19912010 [In Serbian].

27. BELOJEVIĆ G., PAUNOVIĆ K., JAKOVLJEVIĆ B., STOJANOV V., ILIĆ J., SLEPČEVIĆ V., SARIĆTANASKOVIĆ M. Cardiovascular effects of environmental noise: research in Serbia. Noise Health, 13, (52), 217, 2011.

28. NAGY I. Urban ecology. Dialóg-Campus, Budapest-Pécs, 2008 [In Hungarian].

29. CALIXTO A., DINIZ F.B., ZANNIN P.H.T. The statistical modeling of road traffic noise in an urban setting. Cities, 20, (1), 23, 2003.

30. OGNEVA-HIMMELBERGER Y., COOPERMAN B. Spatio-temporal analysis of noise pollution near Boston Logan Airport: Who carries the cost? Urban Stud., 47, (1), 169, 2010.

31. TAYLOR N. The aesthetic experience of traffic in the modern city. Urban Stud., 40, (8), 1609, 2003.

32. STATISTICAL YEARBOOK. National Bureau of Statistics of the Republic of Serbia, Belgrade, 2012.

33. BUBALO-ŽIVKOVIĆ M., DRAGIN A., ĐERČAN B. Gravitational area of Novi Sad. Zbornik radova Geografskog fakulteta, 57, 103, 2009 [In Serbian].

34. INSTITUTE FOR STANDARDIZATION OF SERBIA, Acoustics - Description, measurement and assessment of environmental noise - Part 1: Basic quantities and assessment procedures, SRPS ISO 1996-1:2008 [In Serbian].

35. INSTITUTE FOR STANDARDIZATION OF SERBIA, Acoustics - Description, measurement and assessment of environmental noise - Part 2: Determination of environmental noise levels, SRPS ISO 1996-2:2008 [In Serbian].

36. INSTITUTE FOR STANDARDIZATION OF SERBIA, Building acoustic - Acoustical zoning, SRPS U.J6.205:2007 [In Serbian].

37. INSTITUTE FOR STANDARDIZATION OF SERBIA, Acoustics - Description and measurement of environmental noise, SRPS U.J6.090:1992 [In Serbian]

38. THE ACT OF NOISE INDICATORS, LIMITED VALUES, METHODS FOR EVALUATING OF NOISE INDICATORS, DISTURBANCE AND HARMFUL NOISE EFFECTS IN THE ENVIRONMENT, "Official Gazette", the Republic of Serbia, No. 72/2010 [In Serbian].

39. THE LAW OF PUBLIC HEALTH, "Official Gazette", the Republic of Serbia, No. 72/2009 [In Serbian].

40. THE LAW ON ENVIRONMENTAL PROTECTION, "Official Gazette", the Republic of Serbia, No. 135/2004 [In Serbian].
41. THE LAW ON PROTECTION FROM NOISE, "Official Gazette", the Republic of Serbia, No. 36/2009 [In Serbian].

42. THE REGULATION ON METHODS OF NOISE MEASURING, "Official Gazette", the Republic of Serbia, No. 75/2010 [In Serbian].

43. THE REGULATION ON THE CONTAIN AND METHODS FOR STRATEGIC NOISE MAPS AND WAYS OF THEIR REPRESENTING TO THE PUBLIC, "Official Gazette", the Republic of Serbia, No. 80/2010 [In Serbian].

44. REIMANN C., FILZMOSER P., GARRETT R.G., DUTTER R. Statistical Data Analysis Explained: Applied Environmental Statistics with R, John Wiley \& Sons, Chichester, England, 2008.

45. LI B., TAO S., DAWSON R.W., CAO J., LAM K. A GIS based road traffic noise prediction model. Appl. Acoust., 63 , 679, 2002.

46. FORASTER M., DELTELL A., BASAGAÑA X., MEDINA-RAMÓN M., AGUILERA I., BOUSO L., GRAU M., PHULERIA H.C., RIVERA M., SLAMA R., SUNYER J., TARGA J., KÜNZLI N. Local determinants of road traffic noise levels versus determinants of air pollution levels in a Mediterranean city. Environ. Res., 111, 177, 2011.

47. ZANNIN P. H. T., ENGEL M.S., FIEDLER P.E.K., BUNN F. Characterization of environmental noise based on noise measurements, noise mapping and interviews: A case study at a university campus in Brazil. Cities, 31, 317, 2013.

48. DURMISEVIC S., SARIYILDIZ S. A systematic quality assessment of underground spaces - public transport stations. Cities, 18, (1), 13, 2001.

49. VAN RENTERGHEM, T., BOTTELDOOREN, D. Effect of a row of trees behind noise barriers in wind. Acta Acustica united with Acustica, 88, 869, 2002.

50. VAN RENTERGHEM T., BOTTELDOOREN D. On the choice between walls and berms for road traffic noise shielding including wind effects. Landscape and Urban Planning, 105, 199, 2012.

51. FANG C.-F., LING D.-L. Investigation of the noise reduction provided by tree belts. Landscape Urban Plan., 63, 187, 2003.

52. FANG C.-F., LING D.-L. Guidance for noise reduction provided by tree belts. Landscape Urban Plan., 71, 29, 2005.

53. NAGY I. Urban ecology as the interdisciplinary and applied science discipline about environment. Zbornik radova Departmana za geografiju, turizam i hotelijerstvo, 39, 66, 2010 [In Serbian].

54. KOTZEN B., ENGLISH C. Environmental noise barriers A guide to their acoustic and visual design (second edition). Taylor and Francis, London, 2009.

55. KRISTOFOROVIĆ-ILIĆ M., RADOVANOVIĆ M., VAJAGIĆ L., JEVTIĆ Z., FOLIĆ R., KRNJETIN S., OBRKNEŽEV R. Communal hygiene, University of Novi Sad, Faculty of Medicine, Novi Sad, 1998 [In Serbian].

56. LO A.Y.H., JIM C.Y. Differential community effects on perception and use of urban greenspaces. Cities, 27, 430, 2010.

57. GIDLÖF-GUNNARSSON A., ÖHRSTRÖM E. Noise and well-being in urban residential environments: The potential role of perceived availability to nearby green areas. Landscape Urban Plan., 83, 115, 2007.

58. HOSSEINI S. A., PARSAKHOO A., SEIFI R. Investigating the Effects of Technical Parameters of Forest Road Planning and Building on Traffic Noise Reduction. Pol. J. Environ. Stud., 21, (5), 1217, 2012. 